NBER WORKING. PAPER SERIES

\title{
EQUILIBRIUM AND DISEQUILIBRIUM EXCHANGE RATES
}

\author{
Rudiger Dornbusch
}

Working Paper No. 983

\section{NATIONAL BUREAU OF ECONOMIC RESEARCH 1050 Massachusetts Avenue \\ Cambridge MA 02138}

September 1982

The research reported here is part of the NBER's research program in International Studies. Any opinions expressed are those of the author and not those of the National Bureau of Economic Research. 


\begin{abstract}
Equilibrium and Disequilibrium Exchange Rates

The paper reviews theoretical developments in the field of exchange rate theory and assesses the empirical evidence. Since the empirical evidence does not lend support to the models that have been formulated, a number of reasons for that failure are suggested. These include the argument that the current account has been overrated as an exchange rate determinant and that the role of "news" as yet remains to be tested in an extensive way.

Four exchange rate problems are identified as possibly giving justification to exchange market intervention or other policies. They are the possibility of speculative bubbles, the peso problem, the use of irrelevant information and the problem of real appreciation in the case of monetarist stabilization. In each case the exchange rate can deviate from fundamentals, following the asset market rather than the goods market, and thus disturbing macroeconomic equilibrium.
\end{abstract}

Rudiger Dornbusch E52-357 M.I.T. Cambridge,Mass. 02139

(617) 253-3648 
Revised

June 1982

\section{EQUILIBRIUM AND DISEQUILIBRIUM EXCHANGE RATES*}

Rudiger Dornbusch

Massachusetts Institute of Technology

Milton Friedman's 1950 essay "The Case for Flexible Exchange Rates" brought persuasive argumerts against exchange control and fixed exchange rates and established firmly the proiession's preference for flexible rates. The case rested on a triple advantage: no need for direct controls and inefficiency, the advantage of monetary sovereignity and the convenience of adjusting the exchange rate rather than the entire domestic price structure. The analogy with daylight savings time plainly made the case that "it is far simpler to allow one price to change, namely, the price of foreign exchange, than to rely upon changes in the multitude of prices that together constitute the Internal price structure."l When the collapse of the Bretton Woods system led to flexible rates the profession accepted this as progress; that belief continues and predisposes us to see the experiment with flexible exchange rates as successful.

It is not always easy to believe that the experiment has been an outright success. We do observe large, apparently self-reversing movements in exchange rates, both nominal and real. More importantly, we often have no good idea, either in theory or more informally, in what manner the current level of the exchange rate represents an equilibrium. It is at such times,

*Financial support was provided by a grant from The National Science Foundation. I wish to acknowledge helpful discussions with Olivier Blanchard, JefErey Frankel, Alberto Giovannini, Dale Henderson, Maurice Obstfeld and Robert Shiller.

lFriedman (1953), p. 173. 
of course, that we are reminded of the history of flexible exchange rates in the 1920s, especially the French episode, and the argument of the time that exchange rates were moved, under the influence of speculation, in ways incompatible with fundamentals and aggravating the problems of domestic stabilization. That view had been advanced by Nurkse (1944, p. 118):

"...anticipations are apt to bring about their own realization. Anticipatory purchases of foreign exchange tend to produce or at any rate to hasten the anticipated fall in the exchange value of the national currency, and the actual fall may set up or strenthen expectations of a further fall.... Exchange rates in such circumstances are bound to become highly unstable, and the influence of psychological factors may at times be overwhelming. French economists were so much impressed by this experience that they developed a special 'psychological theory' of exchange fluctuations, stressing the indeterminant character of exchange rates when left to find their own level in a market swayed by speculative anticipations." (p. 118.)

Nurkse's view was challenged by Friedman (1953, pp. 176-77) who argued that no professional case had been made to the effect that speculation was destabilizing. On the contrary, speculation against the currency only anticipated a depreciation bound to come of its own. That criticism has been largely endorsed by the profession and ratified in exchange rate models where the current equilibrium exchange rate correctly reflects the anticipated path of future (exogeneous) money. The exchange rate then is merely a barometer of a government's inflationary intentions.

But such an interpretation misses an important point in Nurkse's laterpretation, namely, that there is an exchange rate indeterminancy because financial policies, which supposedly anchor the system, are in fact endogeneous and may be substantially caused by movements in the exchange rate. It is true that the exchange rate only reflects the possible paths the 
economy might take. But the likelihood of a particularly adverse path becomes higher once speculators' recognition of that possibility is reflected in the exchange rate and, from there, in prices and the requirements of monetary accommodation. This, of course, was very much the scenario that Nurkse was commenting on in pre-Poincare France.

The possibility that flexible rates may adversely affect the macroeconomy is certainly coming to be recognized. The idea of "virtuous and vicious circles" makes that point, as does the notion that flexible rates make the Phillips Curve steeper. ${ }^{2}$ But while it is certainly recognized that flexible exchange rates may not do their work, this is not yet a commonly shared belief. Indeed, it is only the controversy over sterling in 1979/80, the Yen in $1978 / 79$ and the current controversy over the dollar that loudly suggest a fundamental problem with our exchange rate system. ${ }^{3}$

In fact there appear to be several separate problems. One emerges from international real interest differentials that arise in the course of monetary stabilization which lead to real appreciation and disruptive macroeconomic effects abroad. A second is associated with speculative bubbles that remove the exchange rate from a path dictated by fundamentals. In either event the exchange rate assumes a life of its own that may be seriously at odds with macroeconomic stability and that calls for remedies. This is also the case when extraneous beliefs join fundamentals in influencing the market rate.

There is certainly one thing the experience with flexible rates has done and that is to disillusion even the true believer on the subject of monetary sovereignity under flexible rates. That there is no sovereignity

${ }^{2}$ See Gray and Wallich (1979) and Dornbusch and Krugman (1977).

${ }^{3}$ See Appendix 6 to the Treasury and Civil Service Report on Monetary Policy, U.K. House of Commons, London, 1981. 
but rather sharp conflict of interest is brought out by the present dollar problem.

The Financial Times of January 26,1982 in a commentary entitled "\$ Rise undermines European Bid to cut interest rates" notes:

"The fresh wave of higher U. S. interest rates threatens to wreck the independent initiative launched last week by the Bank of England, the West German Bundesbank and other EEC central banks to lower the cost of credit in Europe and speed up economic recovery.

The sharp fall in sterling and other leading European currencies against the dollar yesterday may prolong the European recession just as an upturn had seemed likely.

This is because EEC central banks may be forced to take action to prevent currency depreciation triggering off fresh inflation."

That these concerns go beyond technicalities of day-to-day money markets is represented in a follow-up article on January 28th: "Germans worried by U. S. deficit" which notes:

"However, despite the efforts of European central banks to coordinate a modest fall in interest rates last week, it is stressed here that Europe's scope to "uncouple" itself from U. S. developments remains very small. This is said to apply to West Germany despite its improved current account performance and relatively low inflation rate.

Bonn feels that the upshot may well be a further fall in investment, a rise in unemployment and more social unrest. "All elements of a depression are there," one official stressed.

This paper will take the perspective that exchange rates in the 1970 s have not worked well. From that point of view, we attempt to establish in what ways the exchange rate system may have fallen short of what theory and 
policy beliefs suggest and what possible remedies there are. In the first section exchange rate theories and some empirical evidence are reviewed. The section concludes that theories have across the board failed to account for exchange rate behavior. The next section identifies four specific policy problems: bubbles, the peso-problem, extraneous beliefs and the dollar problem. Each deals with the possibility of disequilibrium exchange rates, although in different, possibly overlapping ways. The last section discusses (and dismisses) intervention as a policy tool and makes a case for real interest equalization taxes.

\section{Exchange Rate Theories}

This section develops the main theoretical approaches to exchange rate determination and comments cursorily on their empirical success. The relevant theories are the monetary approach and the current account approaches in two variants emphasizing imperfect substitutability of assets and goods respectively.

The Monetary Approach

The monetary approach, no doubt, is the most popular model of exchange rate determination, anchored as it is in two outrageous simplifications of the economic scene: purchasing power parity and the quantity theory. The model assumes that national price levels are instantaneously flexible and determined by money supplies and real money demands. Moreover, with the "law of one price" prices are equalized internationally with exchange rate movements offsetting divergent national price trends. 
The monetary approach gives rise to an exchange rate equation that includes relative nominal money supplies, relative velocities and relative levels of real income. In log form the exchange rate equation then becomes:

$$
e=m-m^{*}+\left(v-v^{*}\right)-\left(y-y^{*}\right)
$$

where $e$ is the dollar price of foreign exchange and $m, v, y$ are nominal money, velocity and real income, an asterix denoting the foreign country. Early endeavors with this equation were not unsuccessful, but by now there are, I believe, no more serious claims for the empirical relevance of this model. 4 The Terms of Trade Model.

The monetary model is highly restrictive in its assumption of the law of one price. This is apparent when we move to a transactions version of this model. Suppose $q$ denotes the $\log$ of the expenditure deflator, $a$, is real spending and $v$ now denotes the expenditure velocity. Home money market equilibrium can be stated in terms of the determinants of the expenditure deflator:

$$
q=p+v-a
$$

where $\mathrm{q}$ is a weighted average of home and import prices:

\footnotetext{
${ }^{4}$ For reference see, for example, Dornbusch (1980). See, however, the discussion in the Economic Report of the President, 1982.
} 
(3)

$$
q \equiv x p+(1-x)\left(e+p^{*}\right)
$$

With a simflar specification for the foreign country, and assuming foreign expenditure on domestic goods to have a share $x^{*} \leqslant x$, we derive an exchange rate equation of the form:

$$
e=\left[\left(m-m^{*}\right)+\left(v-v^{*}\right)-\left(a-a^{*}\right)\right]+\left(x-x^{*}\right) \theta
$$

where $\theta \equiv e^{t} p^{*}-p$ denotes the terms of trade.

The extended model maintains the prediction of the monetary approach to the extent that changes in money or velocity are translated into equiproportionate depreciation, given the terms of trade. But now there is another source of exchange rate movement, namely, terms of trade changes. Changes in the equilibrium terms of trade affect the equilibrium exchange rate to an extent that depends, among other factors, on the differential in expenditure shares, $x-x^{*}$.

The extended model is readily applied, in the manner of Fleming and Munde11, to the effects of a shift in demand toward domestic goods. Suppose capital is perfectly mobile and that the home country faces a given, unchanging foreign level of spending and interest rates. Assume also that product prices are given. Figure 1 shows the determination of the exchange rate at point $A$. The IS schedule is positively sloped because a real depreciation creates demand and raises output. The LM schedule is negatively sloped since an appreciation lowers the price level and raises the real money 


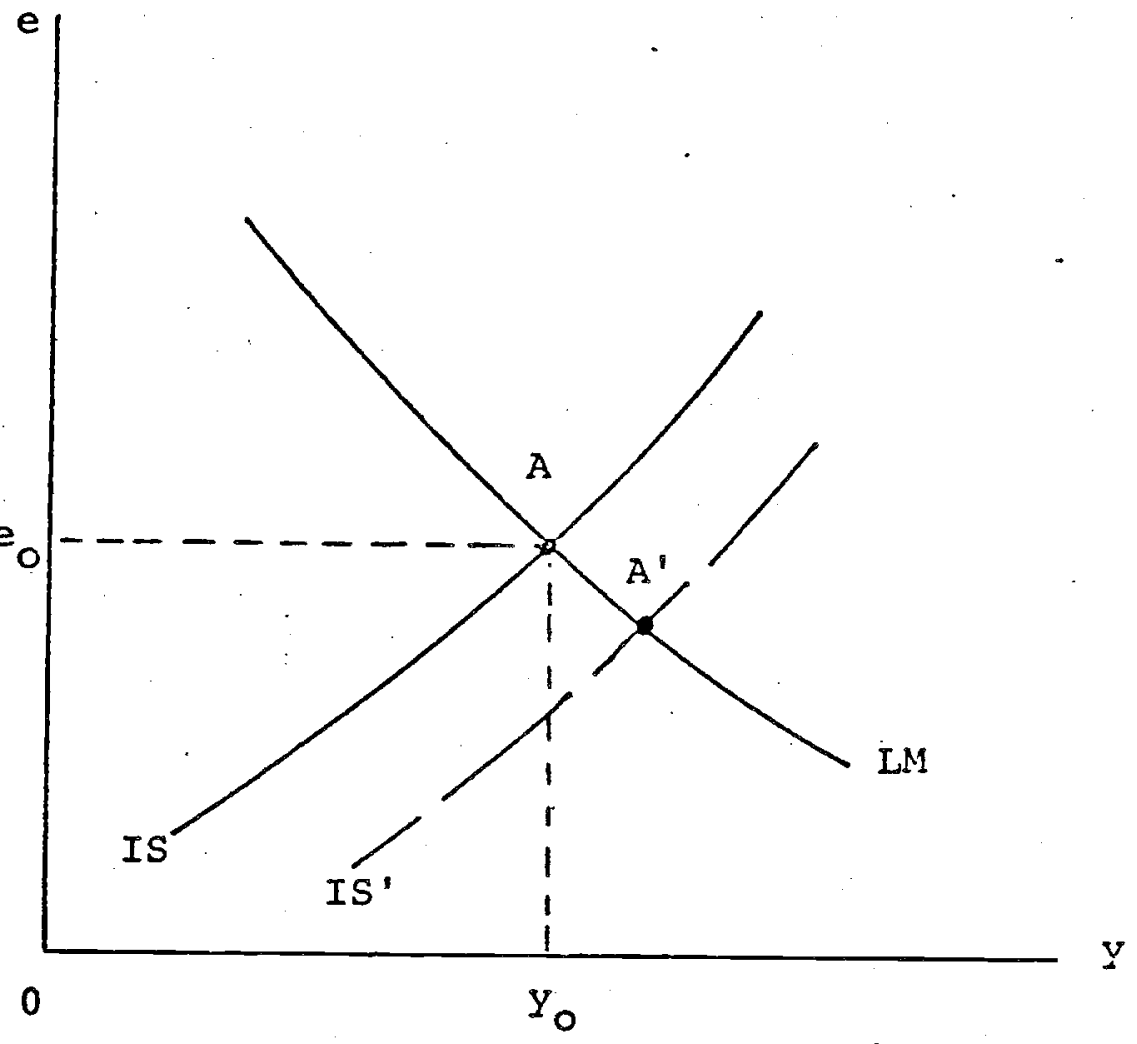

Figure 1. 
stock thus making room for a real expansion. Figure 1 shows that a shift in demand toward domestic goods will raise income and lead to an appreciation. The expansion will be larger the larger the share of importables in the deflatór. By contrast, a large import share in the expenditure deflator will tend to dampen the expansionary impact of a money expansion.

Even before we move to issues of imperfect asset substitution or expectations, exchange rate determination is already a macroeconomic problem involving the interaction of goods and asset markets. Consider now the extension to the case where output adjusts gradually to long-run excess demand and exchange rate expectations conform to perfect foresight. Under the assumption that capital mobility is perfect, home nominal interest rates equal those abroad plus the anticipated rate of depreciation:

$$
i=i *+\dot{e}
$$

In Figure 2, we show the phase diagram, noting that now the rate of depreciation $\dot{e}$, is a determinant of home velocity. From an initial equilibrium at $\mathrm{A}$ a monetary expansion leads to an immediate depreciation at point $A^{\prime}$ on the saddlepath. The exchange rate in the short run must overshoot as output expansion is sluggish. At $A^{\prime}$ the exchange rate has overdepreciated and thus anticipated appreciation lowers velocity relative to a static expectations world. Over time the economy converges to point A" as output expands to meet the increase in demand. The economy proceeds from $A^{\prime}$ to $A^{\prime \prime}$ along the perfect foresight path PP.

The analysis of expectations is readily extended in three directions. One is to add sluggish price adjustment and thus allow long run neutrality. The second extension is to consider the impact of anticipated future shocks. 


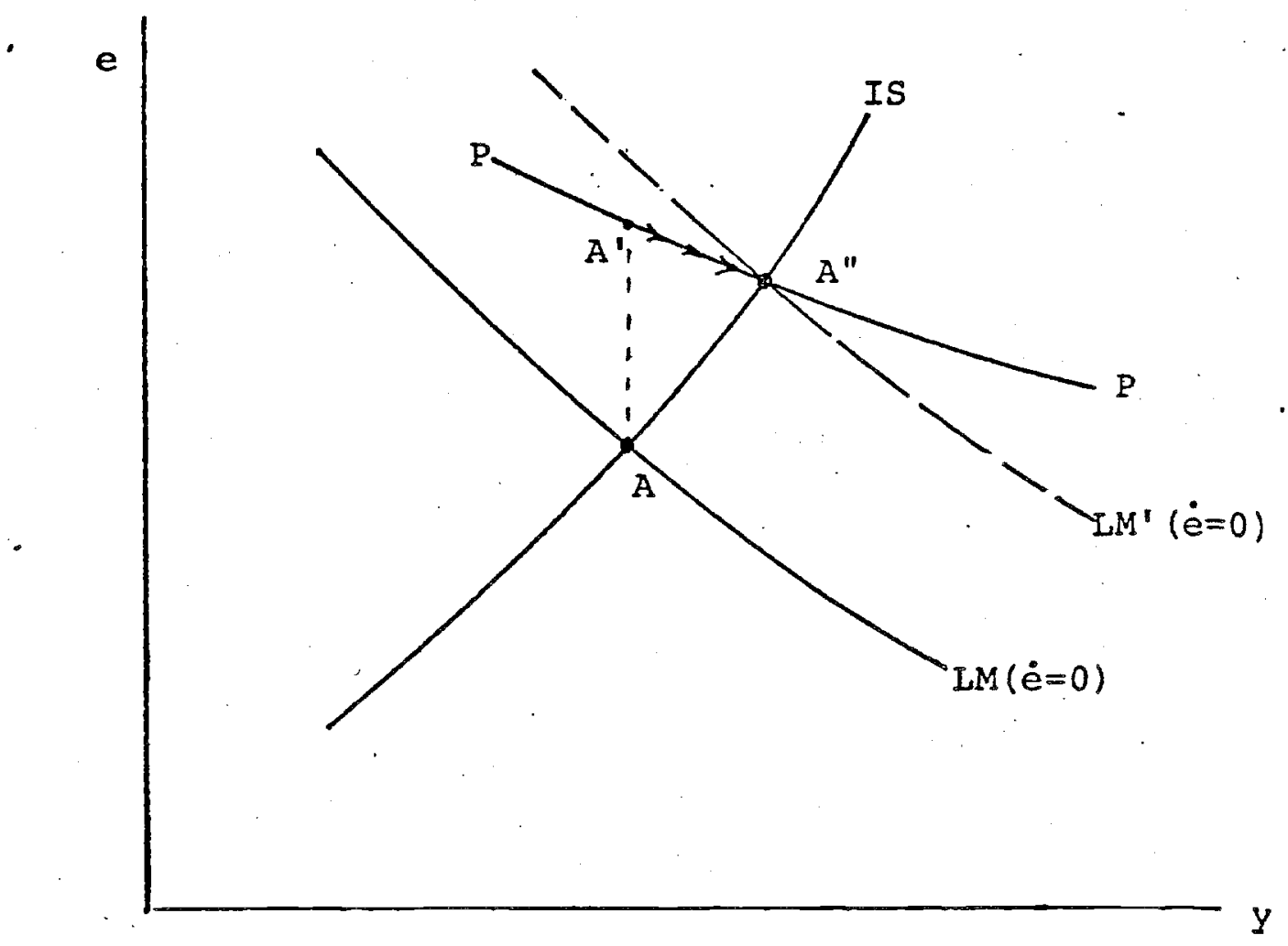

Figure 2 
Third, and perhaps most important, we can introduce an explicit consideration of the current account as a source of dynamics. Current account imbalances, by redistributing net assets internationally, may affect demand to the extent that marginal spending patterns differ. If this is the case, current account imbalances lead to changes in equilibrium relative prices and thus to changes in the exchange rate.

We have reached the point where the current exchange rate is determined not only by current monetary factors--the relative supply and demand of money--but also by prospective monetary factors as well as the present and future demand for goods. An anticipated fiscal expansion, for example, will lead to immediate currency appreciation even though the demand expansion has, as yet, not materialized. But there is one important, conplication still left out, namely, the possibility of imperfect substitution among assets. Imperfect Asset Substitutability

If asset holders are risk averse, and returns on securities denominated in different currencies are not perfectly correlated, risk premia may emerge that depend on relative asset supplies.

A risk premium modifies the relation between interest rates and expected depreciation in (5). The equation now becomes:

$$
1=1^{*}+\dot{\mathrm{e}}+\phi(\mathrm{B} / \overline{\mathrm{W}}, \mathrm{W} / \overline{\mathrm{W}}) ; \phi_{1}>0, \phi_{2}<0
$$

where $B$ denotes the supply of domestic outside nominal assets while $W$ and $\bar{W}$ are home wealth and world wealth all measured in home currency. The extent 
to which the risk premium increases with a rise in the relative supply of domestic currency assets depends on the degree of risk aversion and the variance of relative asset returns. The exchange rate affects the variables $B / \bar{W}$ and $W / \bar{W}$ since it influences the domestic currency value of world wealth. A depreciation lowers the relative supply of domestic assets and domestic relative wealth.

The risk premium model of asset markets, in conjunction with money and goods markets, extends the range of exchange rate determinants which now include the current and prospective relative supplies of nominal outside assets and, possibly, the distribution of world wealth. It is interesting to note, in this context, that imperfect asset substitutability need, by no means, establish a link between current accounts and the exchange rate. Frankel (1979) among others, has noted that what is at issue in the risk premium is the relative supply of nominal outside assets. Privately financed current account imbalances will not affect the world supplies of outside assets. Furthermore, even if the deficits were publicly financed there is no necessity that they be financed in terms of home currency denomination. More importantly, as has been noted, the relative supply of outside nominal assets is also affected by intervention and budget financing, thus obliterating any special role for the current account.

There remains the question whether current accounts, by redistributing world wealth, interact with a preferred domestic habitat in portfolios to change the risk premium and therefore, affect exchange rates. As Krugman (1980) has shown this possibility requires a coefficient of risk aversion larger than unity. Again it must be borne in mind that the relevant measure of wealth in the risk premium will also lnclude real assets so that there is 
typica. $;$ no direct relation between the current account alone and the distribution of world wealth. A stock market boom will have much larger effects on relative wealth than likely current account imbalances.

\section{Empirical Evidence}

Claims for empirically successful exchange rate equations are disappearing rapidly. Recent papers by Franke1 (1982), Isard (1981), Rogoff and Meese (1981) and Hacche and Townsend (1981) all conclude that simple structural models of exchange rate determination all fall to account well for actual exchange rate behavior. This is the case whether a monetary approach is adopted, a Munde11-Fleming-Frankel model or models that include, in addition, current account or relative wealth variables.

Hacche and Townsend (1981, p. 253) summarize their findings as

follows :

"The predominant impresion left by our results is one of failure: we have not succeeded in finding empirical regularities in the data to help explain in any satisfactory way the fundamental determinants of sterling's effectIve exchange rate during the floating rate period. Our research has falled, often dramatically to yield support for any of the theories tested...."

The same conclusion is reached by Meese and Rogoff (1981, p. 23) who conclude:

\footnotetext{
"major bilateral exchange rates and the trade weighted dollar are all well approximated by a random walk. The representative structural models do not perform well out-of-sample; they predict poorly even when uncertainty about future values of the explanatory variables is removed."
}

Isard (1981) and Artus (1982) simflarly find that their tests are unsatisfactory except with the inclusion of a Reagan-dummy. 
There are some reasons why the tests may be falring poorly. First the models tend to give too much emphasis to money supply disturbances neglecting shifts in money demand, fiscal and demand disturbances which, of course, are as impottant as money supply changes. The neglect of demand and fiscal variables in empirical work is, in fact, quite complete.

The more important point is that exchange rate testing has given no room to the role of anticipated future events. But it should be clear that when major changes in the determinants of exchange rates are anticipated they must affect the level of the exchange rate, given current values of the exchange rate determinants. This point is readily made with the help of Figure 3. The economy sits initially at point $A$ and the expectation of a future increase in money and government spending, respectively, occur. The exchange rate will immediately jump in response to the news. In response to an anticipated future money increase it will depreciate to $A^{\prime}$, in response to anticipated higher spending or tax cuts it will appreciate to A".5 Thus given current money and fiscal policy, today's exchange rate may be any of three, $A, A^{\prime}$ or $A^{\prime \prime}$ depending upon whether we anticipate easier money or easier fiscal policy or neither. Neglecting these "news" effects on exchange rates may thus eliminate most of the explanatory variables for the observed noise. This is more likely to be the case the more proximate and larger the anticipated changes.

The same point can be made, using the equation for the relationship between interest differentials, depreciation and the risk premium. Noting that in (6) $\dot{e}$ denotes the expected rate we can write: ${ }^{6}$

$$
\dot{e}_{\text {actual }}=i-i *+\phi(B / \bar{W}, W / \bar{W})+\text { news } "
$$

${ }^{5}$ Wilson (1977) and Rogoff (1979) have studied the role of anticipated future disturbances in exchange rate dynamics. (1980). ${ }^{6}$ On this point see Mussa (1976), Dornbusch $(1978,1980)$ and Isard 


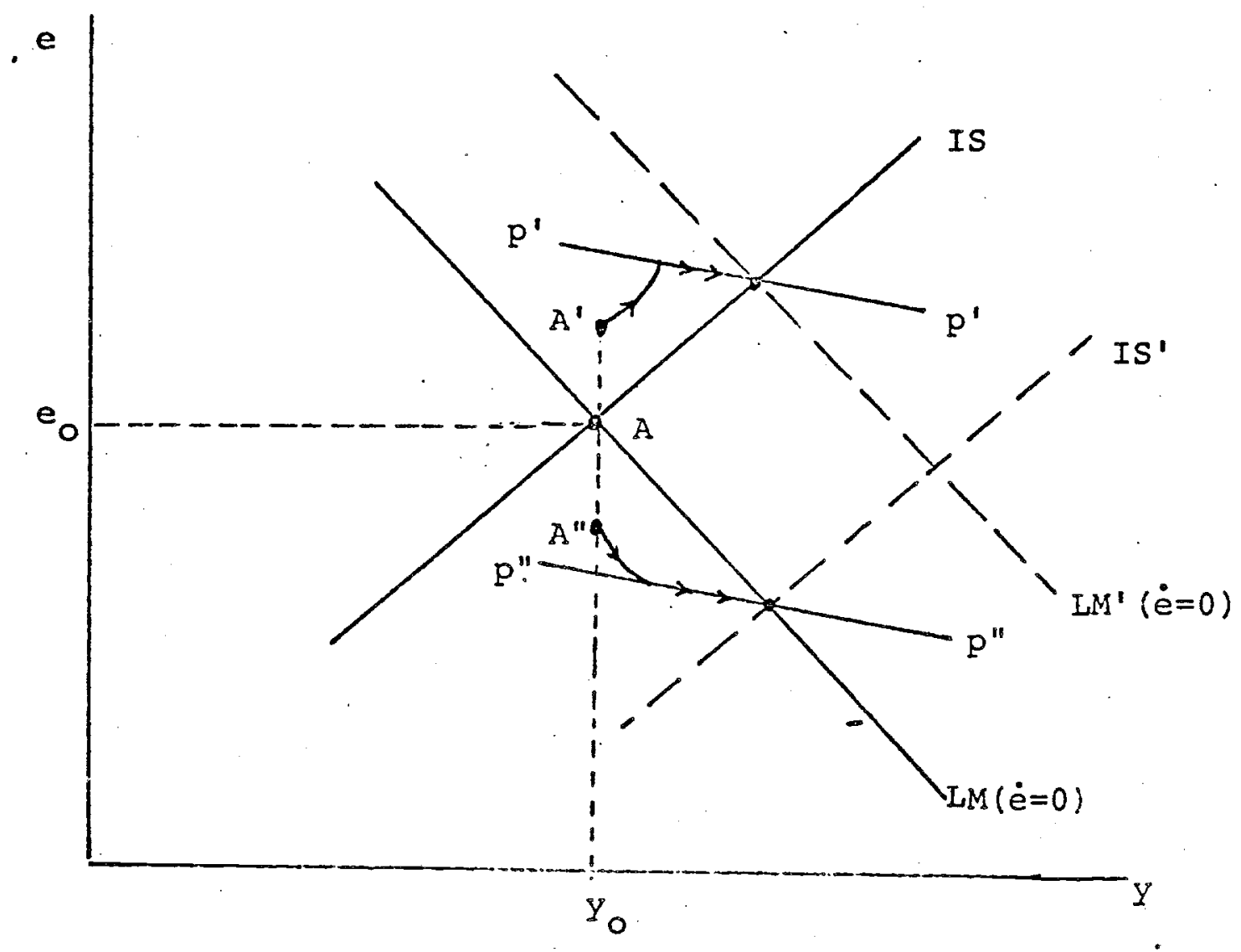

Figure 3 
where we have used the fact that with rational expectations the actual depreciation rate is equal to the expected rate plus a white noise error or "news." Equation (7) singles out news as one of the determinants of movements in the exchange rate. Given current income, money and prices as well as the relative supplies of assets, the exchange rate may appreciate or depreciate because the expectation of a change in exchange rate determinants emerges. While that idea has been immediately accepted in the literature and indeed, reminds us of the 1920 s discussion, it has received practically no empirical testing. ${ }^{7}$

The literature differs sharply from the extensive and careful testing which expectations based macroeconomics has received in closed economy applications. Research here has particularly focussed on questions that run quite parallel: the effect of money, unanticipated versus anticipated, on unemployment and the real rate of interest. ${ }^{8}$ It remains a question whether the very poor empirical performance of exchange rate models is due to a failure to distinguish news and anticipated realizations of the determinants of exchange rates. The work on anticipated future disturbances on the time path of exchange rates, for example, has amply shown that exchange rates may wel1 lead anticipated money.

${ }^{7}$ See, however, Black (1972), Frankel (1981), Dornbusch (1980), Engle and Franke1 (1982) and Corne11 (1982b).

${ }^{8}$ For references see Mishkin (1982). 


\section{Four Problems}

In this section, we sketch four problems that may have arisen under the flexible exchange rate regime of the 1970s. The first is the adverse side effect of inappropriate monetary-fiscal policy mixes. The second concerns the role of expectations about future policy changes that render current policy more difficult, a variant of the peso problem. The third concerns the possibility of speculative bubbles. The fourth involves extraneous beliefs.

Bubbles

Important research on the volatility of asset prices has forced the question whether asset prices move "too much" given the path of fundamentals such as interest rates or dividends. (See, for example, Grossman and Shiller:(1980).) The same question arises in the context of exchange rates. Observing real exchange rates in Chart 1, where we show the Yen and DM rates, we might ask whether this large movement in real exchange rates is warranted by beliefs about the fundamental determinants of exchange rates. Work by Blanchard (1980), Blanchard and Watson (1982) and Tirole (1980) among others discusses the conditions under which speculative bubbles or cumulative divergences from the path warranted by fundamentals may arise. An interesting model is that of Blanchard (1980) where risk neutral speculators are aware that a particular asset price is of the path of fundamentals. Indeed, they expect with probability $\alpha$ a crash and probability $1-\alpha$ the continuation of the bubble.

Suppose domestic and foreign assets are perfect substitutes. The interest rate differential must equal the expected rate of depreciation: 
CHART 1

Real Effective Exchange Rates

$(1975=100)$

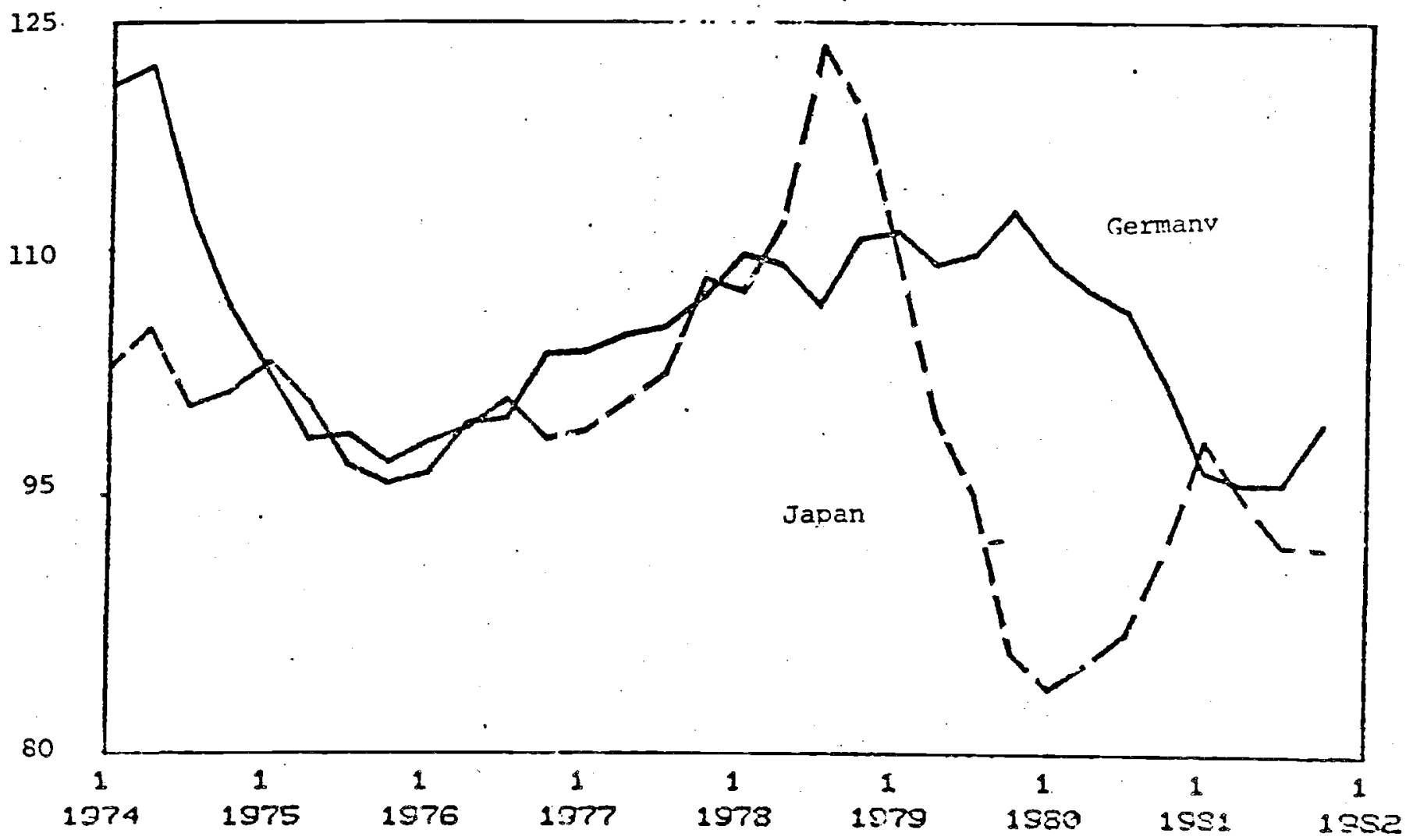

Fource: IMF 


$$
i-i *=\tilde{e}_{t+1}-e_{t}
$$

where $\tilde{e}_{t+1}$ is the expected future exchange rate. But given the probabilities $\alpha$ associated with a crash to the fundamental rate, $\bar{e}_{t}$ and $1-\alpha$ of a continuing bubble, we have:

$$
e_{t+1}-e_{t}=\frac{1-1^{*}}{1-\alpha}+\frac{\alpha}{1-\alpha}\left(e_{t}-\bar{e}_{t}\right)
$$

Equation ( $8 a$ ) describes a "rational" bubble. The exchange rate in the absence of a crash depreciates at a rate determined by three factors: the interest differential, the probability of a crash and the undervaluation, $e_{t}-\bar{e}_{t}$. The more undervalued the exchange rate and the higher the probability of a crash the more rapid the rate of depreciation. A positive interest differential implies depreciation, more so the higher the probability of a crash.

Leaving aside interest differentials, the equation shows the fundamental problem of bubbles: the more overvalued the exchange rate the more rapidly it is appreciating, the more undervalued the more rapidly the rate is depreciating. Bubbles are not self-correcting except by a crash. Bubbles, while they last, involve the possibility of temporary, cumulative deviations from fundamentals.

The presence of interest differentials introduces the possibility that the exchange rate can remain unchanged even though there is over or undervaluation. From ( $8 a)$ we have the special case where the exchange rate remains constant:

$$
\bar{e}-e_{t}=\left(i-i^{*}\right) / \alpha
$$


Thus a positive interest differential in favor of the home country can sustain an overvaluation while a negative interest differential can sustain an undervaluation. 9 The bubble will be larger the larger the interest differential and the probability of a crash. For example, a $20 \%$ probability of a crash and a five percentage point interest differential sustain a $25 \%$ overvaluation!

The analysis has shown the possibility of temporary deviations of the exchange rate from the fundamental rate warranted by "the" model or fundamentals. Why should we be concerned about such deviations? The obvious reason is that given the path of policy variables an exchange rate bubble will have real effects on competiveness, inflation, and employment. It represents a macro-shock that, if possible, we would want to offset. The possibility of rational bubbles is important to recognize because it represents a fundamental departure from the view that markets do things right, all the time.

The Peso Problem

In the case of a bubble, all market participants are aware that the current exchange rate deviates from the fundamental rate, but the bubble may be sustained by new entrants and the belief that it may grow fast enough, thus providing existing asset holders with a comensurate return: A different kind of exchange rate problem emerges when expectations about the path of fundamentals affect the current level of the exchange rate. Such a possibility, particularly when it involves the consideration of a large change in policy regime, has an effect on the current exchange rate and, therefore, on the difficulty of macroeconomic management. Specifically, the expectation of expansionary policy (whether justified or not) will lead to

${ }^{9}$ In ( $\left.8 a\right)$ and (9) the fundamental rate $\bar{e}$ is constant. In a more complete model the question must be raised whether this is consistent with nominal interest differentials. 
current actual depreciation and thus to current inflationary pressures ahead of any expansion. Conversely, the belief in tightening will lead to appreciation and deflationary pressure. This is the so-called "peso-problem."10 Salant and Henderson (1976) have shown that it is a generic problem of asset markets where speculators have to recognize the possibility of a future change in regime that affects future asset prices. The point is illustrated with a simple log-1inear monetary model of the exchange rate in the tradition of Mussa (1975). Suppose there is full purchasing power parfty and price flexibility and that real money demand depends on expected inflation or depreciation:

$$
m_{t}-e_{t}=-b\left(\tilde{e}_{t+1}-e_{t}\right)
$$

Suppose also that next period and ever thereafter the money stock is with probability $(1-\alpha)$ current $m_{t}$ and with probability $\alpha$ equal to $m_{t}+x$. The forward solution to (10) yields a level of the current exchange rate:

$$
e_{t}=m_{t}+\frac{b}{1+b} \alpha x
$$

Thus the higher the probability of an increase in future money the higher is the current equilibrium exchange rate.

The problem raised here is very. much like that of a bubble if the contingencies contemplated by the public are not in fact the intention of policymakers. The rate today is off the equilibrium path that policymakers have in mind for the economy. But there is, of course, the possibility that 10 See Lizondo (1979) and Krasker (1980). 
the fact of a depreciation, due to the beliefs about the possibility of an expansion, will force the actual expansion. Policies are rarely exogeneous and they may be largely or entirely endogeneous. If this were the case, then random variations in beliefs about future policies can shape actual policies and the economy is without anchor.

There is a sense in which the exchange rate, in this setting, behaves exactly right. Asset holders are concerned about the possibility of capital losses and in response to reassessments about the path of policies, they shift their portfolios and thus move the exchange rate. But there is also a sense in which this forward-looking, asset market-oriented adjustment of exchange rates works with an overkill. By adjusting to the whims and fears of the moment, the exchange rate moves, and possibly a lot, and it moves relative to other more stable or sticky prices. Thus the real exchange rate, which guides the international division of labor, is being moved in response to conjectures about the future course of monetary and fiscal policies. The importance of the Peso-problem is well-illustrated by the French experience in 1925-26. While the actual budget was in surplus and inflation was under control, the expectation that debt service should possibly be financed by money creation or capital taxation led to a flight out of the Franc. Chart 2 shows the Franc exchange rate collapsing in early 1926 and then, upon Poincare's assuming office with fiscal dictatorial powers, rapidly appreciating again.

The exchange rate links asset and goods market in a sticky price world. The double allegiance creates trouble because the exchange rate moves like an asset price and not as a real exchange rate should. But movements in 
CHART 2 THE FRENCH FRANC, EFFECTIVE EXCHANGE RATE $(1921 \mathrm{Jan} .=100)$

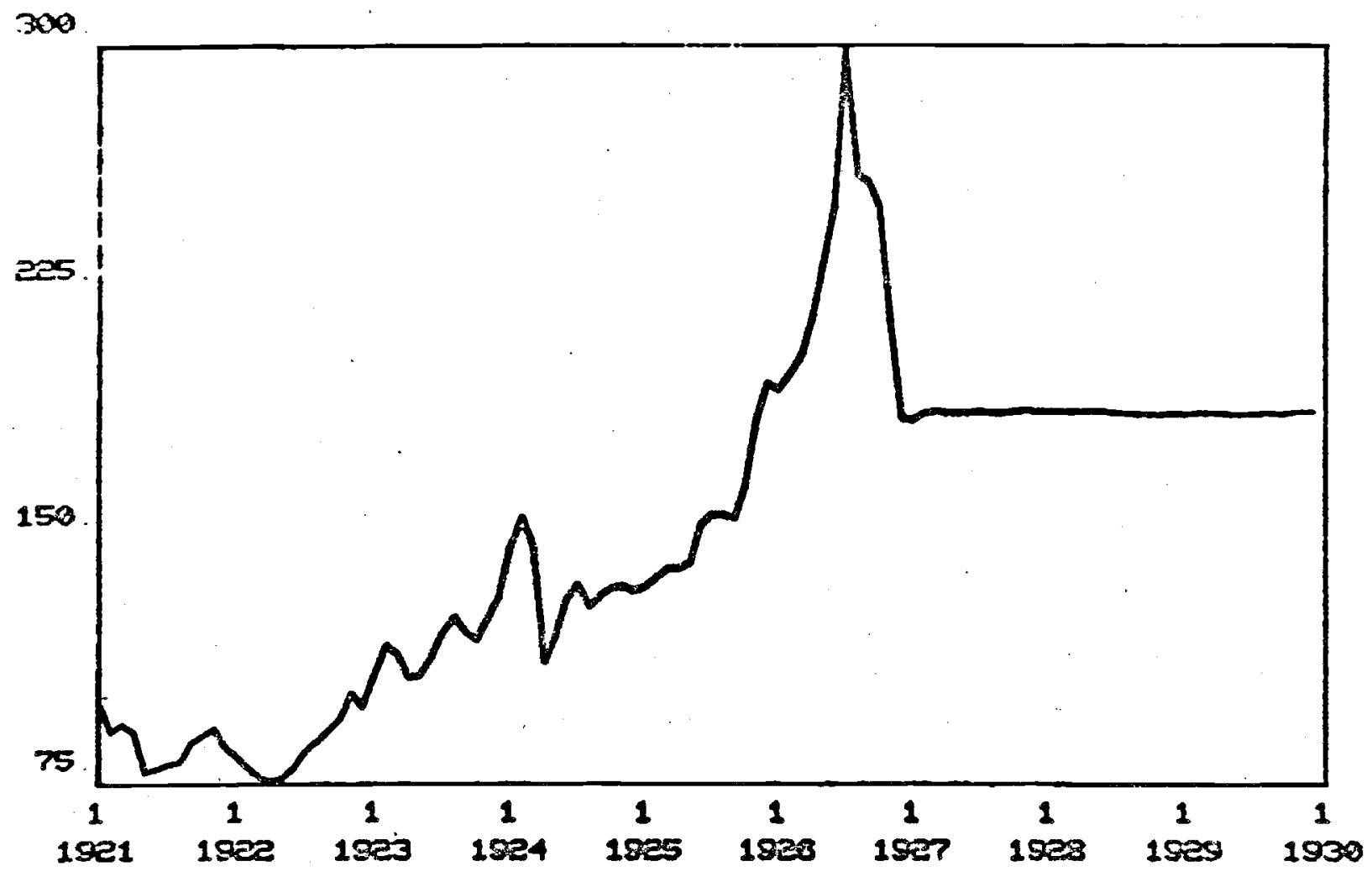


the nominal exchange rate also affect the price level, through import prices, wages and competitive effects. Therefore movements in exchange rates, provoked by changing expectations about policy, have immediate effects on inflation. The moment the public comes to believe that a particular antiinflation program is less likely to succeed, the ensuing exchange rate depreciation will make that a fact. Clearly here we face the unusual problem of a price that may be too flexible.

\section{Extraneous Beliefs}

There is another manner in which the public's perception of the world can lead the exchange rate to deviate from fundamentals. This arises when extraneous beliefs about the determinants of asset prices, via expectations, actually come to influence asset price. This point has been made by Blanchard (1976) in respect to the Phillips curve and by Shiller (1981) in the context of the stock market. If fads, fashions or misperceptions are highly autocorrelated asset prices can persistently and (in finite samples) undiscoverably deviate from fundamentals. The same point can be easily demonstrated in the context of exchange rates.

Suppose the model of the exchange rate is in fact (10) but that market participants believe the exchange rate is influenced by both the money supply and the current account, $c_{t}$ :

$$
\tilde{e}_{t+1}=E m_{t+1}+\phi E\left(C_{t+1}\right)
$$

where the actual current account follows a first-order autoregressive process and the money stock is a constant, $m$, plus white noise: 


$$
c_{t}=\theta C_{t-1}+u_{t}, \quad m_{t+1}=m+v_{t+1} ; 0<\theta<1
$$

with $u_{t}$ and $v_{t}$ white noise. Using (12) and (13) we arrive at the equilibrium exchange rate:

$$
e_{t}=m+k C_{t}+v_{t}^{\prime}, k \equiv b \phi \theta /(1+b), \quad v_{t}^{\prime}=v_{t} /(1+b)
$$

Accordingly, the current account does affect the equilibrium exchange rate even though it is not part of the structural model. Note next that the forecast errors, $e_{t+1}-\tilde{e}_{t+1}$ are given by:

$$
e_{t+1}-\tilde{e}_{t+1}=k u_{t+1}+v_{t+1}^{\prime}-\theta(\phi-k) c_{t}
$$

If the autocorrelation of the current account is high so that $\theta$ is close to unity and if the response of money demand to the alternative cost of holding money $b$, is high, $\theta b /(1+b)$ is close to unity and the coefficient of $c_{t}$ is close to zero. Regressions will not uncover that forecast errors are predictable on the basis of the current account. They cannot reject, except in extremely. large samples, the hypothesis that the forecast errors are white noise.

The example is of interest because it suggests that extraneous beliefs about exchange rate determinants may introduce persistent and large deviations of the exchange rate from fundamentals and that these deviations are undetectable. The full rational expectations exchange rate (setting $\phi=$ 0 ) would be $\bar{e}_{t}=v_{t}^{\prime}+m$ and therefore the deviation from this "fundamentals 
rate," $\bar{e}_{t}$, is equal to $k C_{t}$. The variance of the fundamentals rate is $\frac{2}{e}=$ $s_{v}^{2}$, whereas the asymptotic variance of the rate including current account beliefs is:

$$
s_{e}^{2}=s_{v^{\prime}}^{2}+k^{2} s_{u}^{2} /\left(1-\theta^{2}\right)
$$

It is immediately apparent that with $\theta$ close to unity extraneous current account beliefs introduce a potentially vast variability in the exchange rate.

The Dollar Problem

Since mld 1980, the US dollar has appreclated relative to other currencies and the real exchange rate today is substantially above the levels of 1973 or 1975 . Chart 3 shows the movement of the real exchange rate (relative value added deflators) and also shows the level of US real interest rates. It is apparent that the real depreciation coincided with a move toward positive and higher average real rates.11

Theoretical models built around the idea of sticky prices or inflation rates suggest that a tightening in monetary growth, other things equal, will lead to an immediate appreciation of the real exchange rate in response to higher domestic interest rates and resulting portfolio shifts in favor of domestic assets. But unless there is an ongoing tightening, the move toward tighter money should rapidly translate into falling nominal interest rates and a reduction in inflation. In that adjustment process, the exchange rate would be depreciating (following the initial jump appreciation) at a rate ${ }^{11}$ This is the "Reagan-dummy" referred to above. 
CHART 3 THE US PEAL EXCHANGE RATE AND THE REAL INTEREST RATE

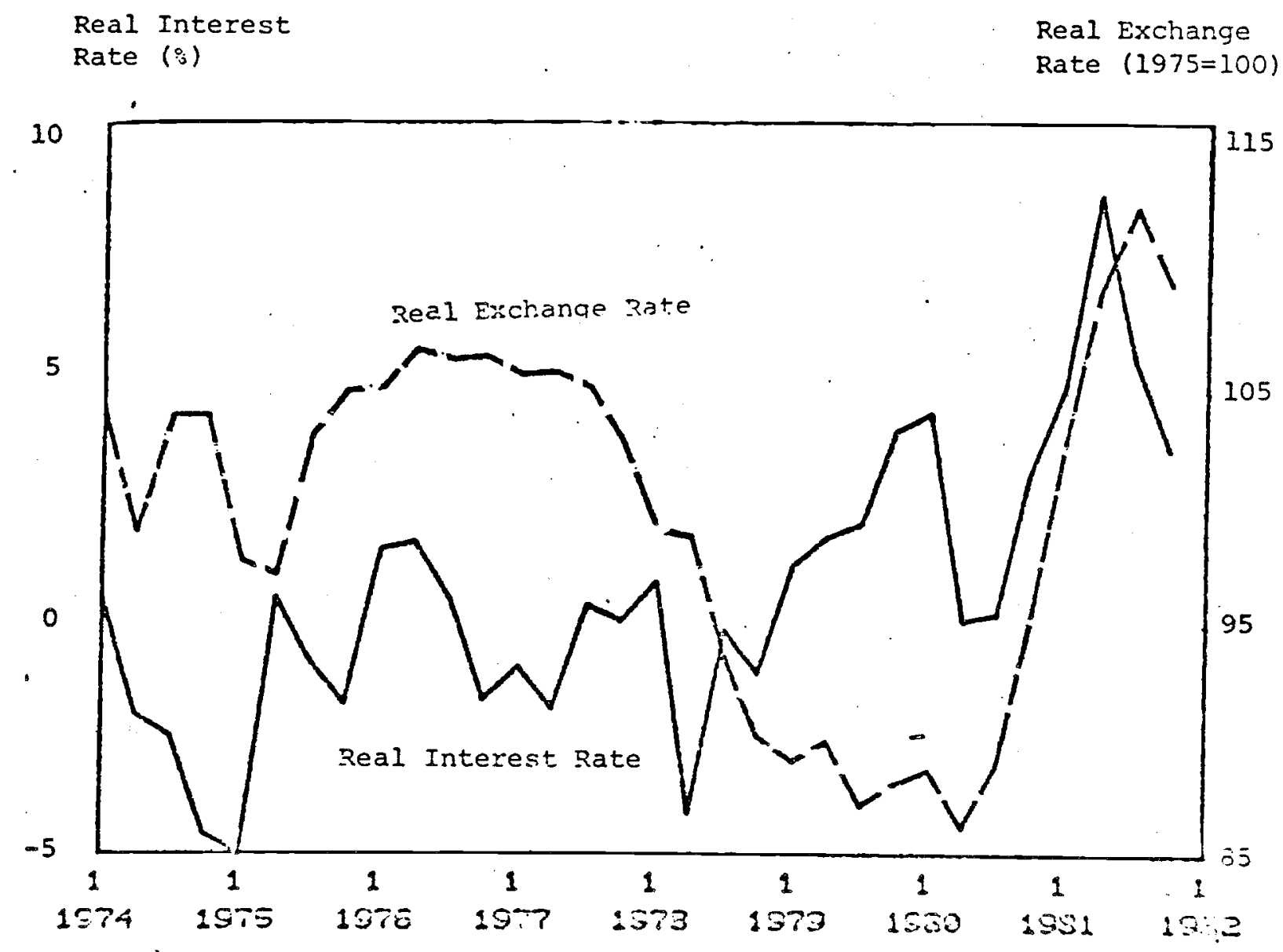

Source:IMF and Morgan Guaranty 
that matches interest differentials adjusted for risk premia. Over the medium term there would be no appreciable change in the real interest rate. Events, in a number of ways, do not fit the theoretical model. On one side there is an accompanying fiscal expansion which both in the short run and in the long run will tend to raise real interest rates. That increase in real interest rates in turn may have a long run effect on the equilibrium exchange rate while reinforcing the short run portfolio shifts. On the other hand, the experiment of monetary tightening is very much in the nature of the "peso problem" that was discussed above. Continuing nominal and real appreciation arises as the public reevaluates its belief in tight money in the light of continuing Fed performance while the Fed itself assesses its course in the light of performance and approval. Thus monetary tightening is itself a medium-term exercise in which progressive tightening interacts with resolve to keep up and belief that this will be the case. The mix allows the possibility of continuing real appreciation over a two or three year period, the more so if inflation is sticky.

Monetary stabilization, certainly in combination with fiscal expansion, cannot fail to raise the real interest rate in the short run and therefore, to lead to international portfolio re-shuffling in favor of the dollar. The portfolio shifts, in turn, induce currency appreciation both in real and in nominal terms. That appreciation, which is an international side effect of our domestic stabilization policies, is a serious macroeconomic problem as the following evidence shows. 
Table 1 shows estimates by the Federal Reserve, using their multicountry trade and payments model, of the $20 \%$ dollar appreciation on a trade weighted basis, on growth and inflation.

Table 1

Estimate of the Effects of a $20 \% \%$ Dollar Appreciation in 1980:3 to 1980:4

Incremental Inflation

$1981 \quad 1982 \quad 1983$
Incremental Growth

1981. $1982 \quad 1983$
Germany

US
1.6

1.4

.7

$-0.5-0.1$
$.3 \quad 2.4 \quad 2.1$

$-.5 \quad-0.4 \quad 1.1$

Source: Hooper (1982).

The OECD has also reported estimates of the effects of exchange rate changes in their multilateral model. Here the effects of a $10 \%$ dollar depreciation are studied, with the depreciation occurring at the outset. 
Table 2

OECD Estimate of the Effects of a $10 \%$ Dollar Depreciation

(at annual percentage rates)

\begin{tabular}{|c|c|c|c|c|c|c|c|c|}
\hline \multirow[b]{2}{*}{ Half-Year } & \multicolumn{4}{|c|}{ Incremental Inflation } & \multicolumn{4}{|c|}{ Incremental Growth } \\
\hline & $1 \mathrm{st}$ & $2 n d$ & $3 \mathrm{rd}$ & 4 th & 1st & 2nd & $3 \mathrm{rd}$ & $4 \mathrm{th}$ \\
\hline North America & 0.4 & 0.7 & 0.3 & 0.1 & -0.2 & 0.1 & 0.4 & 0.3 \\
\hline Europe & -0.5 & -0.1 & -0.6 & -0.3 & 0.0 & -0.2 & -0.4 & -0.3 \\
\hline
\end{tabular}

Source: OECD Economic Outlook, December 1981, pp. 124-125.

The simulations of either model bring out clearly that exchange rates have a very strong impact on inflation and that they also affect real acitivity. A dollar appreciation will reduce US inflation and raise inflation in Europe. Either model suggests that within a year, a $20 \%$ dollar appreciation would raise the European price level about $3 \%$ above what it would otherwise be. That is a very large inflation shock; it certainly is of the same order as the oil price shock. The inflationary shock is particularly large when there is comprehensive indexation that translates higher import prices into increased unit labor costs and thus speeds comprehensively through the economy.

The inflation shock is accompanied by a change in real GNP growth made up of two opposing tendencies. The terms of trade deterioration in Europe lowers real GNP directly. But there is an offset due to increased 
competitiveness that increases trade volume. Both sets of estimates show that ultimately the gain in competitiveness increases growth of real GNP, and quite strongly so in the Federal Reserve model. The OECD model, by contrast, shows both slower and smaller responses of growth.

Now it must be recognized that Europe can expand aggregate demand and raise growth, should she wish to do so. We can therefore not count the growth benefits of the dollar appreciation as an important offset against the imported inflation. In fact, what we must assume is that Europe in an attempt to contain inflation--after all, that is what every country is trying hard to do--must spend the gain in growth and quite a bit more to confine or offset the inflationary impact. This implies not only a reduction in growth but quite possibly too an environment less hospitable to investment. On balance then the dollar appreciation represents an adverse supply shock for Europe. There remains some scope for Europe to affect the composition of the shock between Inflation and recession or reduced growth.

In the US, the exchange rate appreciation exerts a favorable effect on inflation, although the effect is small compared to those in Europe. The impact on growth is negative but small. It is apparent, therefore, that the US interests and those of other counties are sharply opposed. What to the US is a favorable side effect to tight money represents an adverse effect abroad. The question then must be whether these spill-over effects are part and parcel of a well functioning exchange rate system or whether they represent an important shortcoming that needs serious consideration and remedy.

There is another respect in which US policies, and the changed policy environment, contribute to instability. Engle and Frankel (1982) report that 
money surprises--deviations of the Friday release of money data from forecasts--exert a significant effect on short term interest rates and on exchange rates. Cornell (1982) reports the astounding fact that these money news move not only the very short term rate, as might be expected when Fed correction of money is anticipated, but also the whole maturity structure up to 30 years bonds. The fact that the entire interest rate structure moves up in response to weekly money forecast errors reflects the fact that expectations about long term rates have become very diffuse and that now the short term is more nearly thought of as a random walk. In such a world volatility of interest rates may well bring about larger volatility of exchange rates.

3. What is to be Done?

We have identified several problems that place in question the effective operation of the flexible exchange rate system. All issues arise because exchange rates are and behave like asset prices but do play an important role in goods markets as well. We now have to ask whether there are policy remedies to these problems and whether the possible remedies are cost effective. It is important to say at the outset that these issues are unresolved.

There are two possible avenues for influencing and controlling the behavior of exchange rates: one is (sterilized) intervention, the other is a real interest equalization tax (RIET). The case for intervention has been and is an uncomfortable one. The case for a RIET is, at first sight, more controversial, but is an avenue that in view of North Atlantic discord and disruption becomes increasingly realistic as an option. 


\section{Intervention}

The case for intervention rests on the premise that domestic and foreign currency securities are imperfect substitutes and that, accordingly, changes' in their relative supplies will induce portfolio disequilibria. At going interest rates there is a pressure for exchange rate adjustments and these adjustment in turn spread to other financial markets as well as to the goods markets. It is thus possible, on the premise of imperfect asset substitutability, to influence exchange rates by affecting the relative supplies of home and foreign currency outside securities or by management of the currency composition of world debt.

Henderson (1982) offers a definitive analysis of the case for intervention. He concludes that intervention is optimal (if feasible) in the case of portfolio shifts, which of course is the traditional case for accommodating financial policies. For disturbances to aggregate demand, by contrast, a policy of maintaining non-interventionn in money and exchange markets offers greater employment stability. The latter point is readily made with standard aggregate demand and supply schedules as shown in Figure 4. The money wage is assumed fixed but prices are flexible. Thus there is an upward sloping aggregate supply $A_{s} \cdot$ The aggregate demand schedule $A_{d}$, embodies bond and money market equilibrium, given the alternative policy assumptions. Along the steeper schedule exchange and interest rates are held constant. Therefore, a decline in prices stimulates aggregate demand only through the effect on competitiveness. Along the dashed and flatter aggregate demand schedule money and debt are held constant. Therefore, a fall in prices lowers interest rates and expands demand while at the same time, for bond markets to clear, it induces a depreciation and thus 
reinforces the gain in competitiveness. Accordingly, a larger rise in output is required to restore balance.

A given autonomous increase in demand shifts the aggregate demand schedules out and to the right, the more so the more accommodating are policies. If interest rates and exchange rates are held constant, the demand expansion is not dampened by higher interest rates and appreciation. Accordingly, under such a "rates constant" policy as Henderson concludes, demand disturbances have a larger impact on employment and domestic prices (point $B^{\prime \prime}$ ) than is the case for an aggregate policy (point $B^{\prime}$ ). There are significant complications to the model once we allow, as we should, supply side effects of exchange rate movements. Once these complications are introduced it becomes much less clearcut whether rates constant policies are preferred to policies that maintain aggregates. It also becomes more difficult to identify what is the disturbance that is affecting the economy. On both counts the case for an active intervention stance becomes less clearcut, except for obvious portfolio shifts.

The ambiguity in the assessment of intervention is increased once we consider the imperfect substitution issue. There is, of course, no question that dollar and foreign currency assets are imperfect substitutes. This is the case because their returns are not perfectly correlated and in some cases are, in fact, negatively correlated. But there remains the question whether the variance of relative returns and the degree of risk aversion are sufficiently large to make imperfect substitutes an easy policy channel. Long and short bonds are imperfect substitutes but twisting the term structure through debt management never was a success. The same question 
arises in the exchange rate context: how large an intervention is required to move the $\$ / D M$ rate $1 \%$ ? To that question we have no serious answer.

If intervention does not look like a very reliable tool, are there any options?' One option is a (moving) wide exchange rate band within which rates are flexible but at the margins of which rates would be defended. Such a band might be reasonable as a proposition to eliminate extreme risk. But in doing so we may also increase the mobility of capital and actually aggravate exchange rate instability within the band. The only sense of a band would be as a cooperative venture in forestalling disruptive policies to spill over into excessive appreciation or depreciation. But it is also conceivable that such band setting may well assume protectionist overtones. On balance, there are serious doubts about such a policy.

The case for intervention is usually made as one of countering disorderly market conditions.12 But there is no very good case why small noise in the market should be smoothed, and there is good reason that large noise cannot effectively be dealt with. A massive disturbance such as the dollar appreciation of 1980-82 probably cannot be dealt with by intervention, unless we allow the exchange authorities to have swings in the size and denomination of their assets. For such massive disturbances we need a more adequate tool.

Real Interest Equalization Taxes

History is aplenty with collapse and surges in exchange rates, whether we look at France in the 1920s, the US in the last years, or the laboratory experiments in Latin America. Invariably, the really vast changes in real exchange rates are associated not with changes in comparative advantage but rather with the medium-tern adjustment to abandon of fiscal control or, on 12 See Economic Report of the President, 19ع2, pp. 189-191. 
the other side, monetary stabilization. Taking the case of monetary tightening, real exchange rates easily move by 20 or 40 percentage points and therefore have, of course, vast effects on the economy over and above what tight money implies. In a small country, these effects are largely domestic, but when the policy is pursued in the US, unsynchronized with the rest of the world, then the policy spills over as an adverse disruptive supply shock abroad. In the trade field, market disruption is dealt with by quotas or ad hoc compensating duties. This is felt to be an effective policy dealing with a transitory disturbance. Much the same view should be adopted on capital account. Whenever unsynchronized policies open up disruptively large real interest differentials, we need ad hoc real interest equalization taxes that close the gaps and avoid a major impact on the real exchange rate. 13 There is no sensible argument that tightening of money should involve as a desirable side effect a loss of exports, an increase in imports, and international redistribution of real income and borrowing abroad. Because these side effects are undesirable, both here and abroad, we should attempt to the maximum possible extent to immunize the world economy against these spillovers.

Ad hoc duties to offset trade disruption are neither totally efficient nor totally effective. But nobody questions that they substantially accomplish their purpose of insulating an industry from some transitory foreign disturbance. The same applies to an RIET. There is little doubt that some inefficiency is involved and that certainly more than the case of trade disruption duties, there is room for circumvention. But that is also

13 Tobin (1978) has argued for a permanent tax on foreign currency transactions. Liviatan (1979) argues for transitory taxes assoicated with monetary stabilization. 
true for all kinds of taxation and taxes, roughly, do work. But it is also true that a RIET is a highly desirable, second-best, instrument.

A real interest equalization tax is a second-best instrument in that at some efficiency costs, it avoids the even larger costs of adverse spillover of US policies abroad. The first-best world is one where transition to lower inflation has no real effects whatsoever, but proceeds with full employment and constant real interest harmony. The moment that scenario is disturbed because prices or inflation rates are sticky, there is a presumption that supplementary policies, both domestic and international, should accompany tight money. The relevant criterion by which to judge supplementary policies (tips, wage controls, investment tax credits, RIETs) is whether on balance they make the economy operate more efficiently without prejudicing the disinflation target. Surely, that must be the case for RIETs since they avoid, if effective, the adverse and totally unwarranted effects of US policies abroad. The argument against RIETs is that they are costly since they interfere with the free flow of capital. But that argument is empty since it falls to demonstrate that the costs of an RIET are larger than the benefits gained thereby in avoiding the spillover of US policy abroad. At present, we are spending a percent or more of GNP every year to try to reduce inflation. We cannot seriously argue that the allocational costs of RIETs are in any sense commensurate with the costs that are avoided by their preventing imported inflation in Europe. 


\section{References}

Artus, 'J., "Effects of U. S. Monetary Restraint on the DM/\$ Exchange Rate and the German Economy, unpublished manuscript, International Monetary Fund, 1981.

Black, S. W., "The Use of Rational Expectations in Models of Speculation," Review of Economics and Statistics, May 1972, pp.161-165.

Blanchard, 0. J., "Speculative Bubbles, Crashes and Rational Expectation," in Economic Letters, North-Holland Publishing Company, 1979, pp. 387389.

, Three Essays on Macroeconomics, unpublished Ph.D. dissertation, M.I.T., 1976.

and M. W. Watson, "Bubbles, Rational Expectations, and Financial Markets," unpublished manuscript, January 1982.

Buiter, W. H. and M. Miller, "Monetary Policy and International Competitiveness: The Problems of Adjustment," Oxford Economic Press, Volume 33, Clarendon Press, Oxford, supplement, July 1981.

Cornell, B., "Money Supply Announcements and Interest Rates: Another View," unpublished manuscript, University of California, Los Angeles, 1982a.

, "Money Supply Anouncements, Interest Rates and Foreign Exchange," unpublished manuscript, University of California, Los Angeles, $1982 \mathrm{~b}$.

Dornbusch, R., Open Economy Macroeconomics, Basic Books, 1980.

, "Exchange Rate Economics: Where Do We Stand?" Brookings Papers on Economic Activity, 1, 1980, pp. 143-185.

, "Exchange Risk and the Macroeconomics of Exchange Rate Determination," unpublished manuscript, M.I.T., 1980.

, "Monetary Policy under Exchange Rate Flexibility," in Federal Reserve Bank of Boston, Conference Series, Managed Exchange Rate Flextbility, 1978 .

and S. Fischer, "Exchange Rates and the Current Account," American Economic Review, September 1980.

and P. Krugman, "Flexible Exchange Rates in the Short Term," Brookings Papers on Economic Activity, 3, 1976. 
Engle, C. and J. Frankel, "Why Money Announcements Move Interest Rates: An Answer from the Foreign Exchange Risk," unpublished manuscript, University of California, Berkeley, 1982.

Flood, Robert, "Stochastic Process Switching and Inflation," unpublished manuscript, Board of Governors of the Federal Reserve, 1982.

and P. M. Garber, "Bubbles, Runs and Gold Monetization," unpublished manuscript, University of Virginia, October 1981. and N. P. Marion, "Exchange Rates Regimes in Transition: Italy 1974," International Financial Discussion Papers, No. 193, November 1981.

Frankel, J., "On the Mark: A Theory of Floating Exchange Rates Based on Real Interest Differentials," American Economic Review, September 1979.

, "The Diversifiability of Exchange Risk," Journal of International Economics, September 1979.

- "Tests of Monetary and Balance of Payments Models of Exchange Rates," University of California, Berkeley, 1982.

Frenkel, Jacob. "Flexible Exchange Rates in the 1970s," Journal of Political Economy, August 1981.

Friedman, M., "The Case for Flexible Exchange Rates," in Essays in Positive Economics, University of Chicago Press, 1956.

Grossman, S, and R. Schiller, "The Determinants of the Variability of Stock Prices," American Economic Review, May 1981.

Genberg, H., "Effects of Central Bank Intervention in the Foreign Exchange Market," IMF Staff Papers, September 1981.

Hacche, G. and J. Townsend, "Exchange Rates and Monetary Policy" Modelling Sterling's Effective Exchange Rate, 1972-80," Oxford Economic Papers, Volume 33, July 1981 .

Henderson, D., "Exchange Market Intervention Operations: Their Effects and Their Role in Financial Policy," unpublished manuscript, Board of Governors of the Federal Reserve System, 1982.

Hooper, P., "Impact of the Recent Dollar Appreciation on GNP and Prices in Major Industrialized Countries: Simulations with the MCM," unpublished memorandum, Board of Governors of the Federal Reserve, 1982.

Isard, P., "Expected and Unexpected Exchange Rate Changes," unpublished manuscript, Federal Reserve Board, 1980. 
Krugman, P. "Consumption Preferences, Asset Demands and Distribution Effect in International Financial Markets," unpublished manuscript, M.I.T., 1980 .

Liviatan, N., "Neutral Monetary Policy and the Capital Import Tax," unpublished manuscript, Hebrew University, October 1979.

Lizondo, J. S., "Foreign Exchange Futures Prices under Fixed Exchange Rates," unpublished manuscript, ITAM, May 1980.

Marris, S., "Exchange Rates: Too Fixed or Too Flexible?" unpublished manuscript, Organization for Economic Cooperation and Development, 1981.

Meese, R. and K. Rogoff, "Empirical Exchange Rate Models of the Seventies: Are They Fit to Survive?" International Finance Discussion Papers, No. 184, June 1981.

Mishkin, F., "Does Anticipated Monetary Policy Matter? An Econometric Investigation," Journal of Political Economy, February 1982.

Mussa, M., "The Empirical Regularities in the Behavior of Exchange Rates and Theories of the Foreign Exchange Market," Carnegie Rochester Conference Series, Volume 11, 1979.

, "The Exchange Rate and the Balance of Payments," Scandinavian Journal of Economics, 2, 1976.

-, "Three Times the Transfer Problem Plus David Hume," unpublished manuscript, University of Chicago, 1969.

Nurkse, R., International Currency Experience: Lessons of the Inter-War Period, League of Nations, Princeton Universicy Press, Princeton, New Jersey, 1944.

Obstfeld, M., "Can We Sterilize?" American Economic Review, forthcoming, 1982 .

Rogoff, K., "Essays on Expectations and Exchange Rate Volatility," unpublished manuscript, Ph.D. dissertation, M.I.T., 1979.

Salant, S. and D. Henderson, "Market Anticipations of Government Policies and the Price of Gold," Journal of Political Economy, 4, 1978.

Shiller, R., "The Use of Volatility Measures in Assessing Market Efficiency," Journal of Finance, May 1981.

Tirole, J., "On the Possibility of Speculation under Rational Expectations," unpublished manuscript, M.I.T., December 1980. 
Tobin, J., "A Proposal for International Monetary Reform," Cowles Foundation Discussion Paper 506, Yale University, 1978.

Wallich, H. and J. A. Gray, "Stabilization Policy and Vicious and Virtuous Circles," in J. Chipman and Charles P. Kindleberger, (eds.), Flexible Exchange Rates and the Balance of Payments, North Holland, 1980.

Williamson, J., The Open Economy and the World Economy, Basic Books, forthcoming.

Wilson, C., "Anticipated Disturbances and Exchange Rate Dynamics," Journal of Political Economy, September 1979. 